\title{
TANGGUNG JAWAB PIDANA TERHADAP PELAKU TINDAK PIDANA \\ PERAMPASAN HARTA BENDA SESEORANG (BEGAL)
}

\author{
MOH. ZAINOL ARIEF \\ Fakultas Hukum Universitas Wiraraja Sumenep \\ sobarchamim@gmail.com
}

\begin{abstract}
ABSTRAK
Kejahatan perampasan harta benda merupakan suatu perbuatan melawan hukum yang sering terjadi dan sangat menimbulkan keresahan di dalam kehidupan bermasyarakat. Tindak kejahatan bisa dilakukan secara tidak sadar, yaitu difikirkan, direncanakan dan diarahkan pada satu maksud tertentu secara sadar benar, namun bisa juga dilakukan secara setengah sadar; misalnya didorong oleh impuls-impuls yang hebat, didera oleh dorongan-dorongan paksaan yang sangat kuat (kompulsi-kompulsi), dan oleh obsesi-obsesi. Untuk menemukan akar masalah dan penanggulangan masalah tersebut, perlu adanya pengkajian secara komprehensif dengan menggunakan pendekatan secara kriminologi dan viktimologi. Tujuan dalam penelitian ini, yaitu : pertama, untuk mengkaji dan menganalisa terhadap korban akibat kejahatan tindak pidana perampasan harta benda dan kedua, untuk mengkaji dan menganalisa sanksi terhadap pelaku tindak pidana perampasan harta benda seseorang. Metode pendekatan masalah yang digunakan oleh peneliti dengan cara menggunakan yuridis normatif dimana mengkaji peraturan perundang-undangan mengenai tanggung jawab pidana terhadap pelaku tindak pidana perampasan harta benda seseorang (begal).
\end{abstract}

Kata kunci :Pertanggungjawaban, Tindak Pidana, Harta Benda.

\section{A. PENDAHULUAN}

Di Dalam buku II KUHP telah dirumuskan secara sempurna, artinya dalam rumusannya memuat unsur-unsur secara lengkap, baik unsur-unsur obyektif maupun unsur-unsur subyektif. Unsur obyektif dapat berupa; unsur perbuatan materiil, unsur benda atau barang, unsur keadaan yang menyertai obyek benda, unsur upaya untuk melakukan perbuatan yang dilarang, unsur akibat konstitutif. Unsur subyektif dapat berupa unsur kesalahan, unsur melawan hukum.

Secara yuridis formal, kejahatan adalah bentuk tingkah laku yang bertentangan dengan moral kemanusiaan (immoril), merugikan masyarakat, asocial sifatnya dan melanggar hukum serta undang-undang pidana didalam perumusan pasal-pasal kitab undang-undang hukum pidana (KUHP).

Tindak kejahatan bisa dilakukan secara tidak sadar, yaitu difikirkan, direncanakan dan diarahkan pada satu maksud tertentu secara sadar benar, namun bisa juga dilakukan secara setengah sadar; misalnya didorong oleh impuls-impuls yang hebat, didera oleh dorongan-dorongan paksaan yang sangat kuat (kompulsi-kompulsi), dan oleh obsesi-obsesi. Misalnya, karena terpaksa untuk mempertahankan hidupnya, seseorang harus melawan dan terpaksa 
membalas menyerang, sehingga terjadi peristiwa pembunuhan.

Berkaitan dalam asas hukum pidana yaitu Geen straf zonder schuld, actus non facit reum nisi mens sir rea, (bahwa tidak dipidana jika tidak ada kesalahan, maka pengertian tindak pidana itu terpisah dengan yang dimaksud pertanggung jawaban tindak pidana). Dalam kebanyakan rumusan tindak pidana, unsur kesengajaan atau yang disebut dengan opzet merupakan salah satu unsur yang terpenting. Dalam kaitannya dengan unsur kesengajaan ini, maka apabila didalam suatu rumusan tindak pidana terdapat perbuatan dengan sengaja atau biasa disebut dengan opzettelijk.

Sistem pertanggung jawaban pidana dalam hukum pidana positif saat ini menganut asas kesalahan sebagai salah satu asas disamping asas legalitas. Sistem pertanggung jawaban pidana dalam hukum pidana nasional yang akan datang menerapkan asas tiada pidana tanpa kesalahan yang merupakan salah satu asas fundamental yang perlu ditegaskan secara eksplisit sebagai pasangan asas legalitas. Kedua asas tersebut tidak dipandang syarat yang kaku dan bersifat absolut. Oleh karena itu memberi

kemungkinan dalam hal-hal tertentu untuk menerapkan asas tanggung jawab mutlak (strict liability), pertanggung jawaban pidana pengganti (vicarious liability), Pertanggung jawaban akibat (erfolgshaftung), kesesatan atau kesalahan (error), alasan pemaaf/ pengampunan hakim ( rechterlijk pardon), Pertanggungjawaban pidana tidak hapus oleh sifat darurat keadaan (culpa in causa) dan pertanggung jawaban pidana yang berhubungan dengan masalah subjek tindak pidana. Maka dari itu ada pula ketentuan tentang subjek berupa korporasi. Semua asas itu belum diatur dalam KUHP (Wvs).

Dilihat dari sudut perbandingan KU HP Negara lain,asas kesalahan atau asas culpabilitas pada umumnya diakui sebagai prinsip umum. Perumusan asas ini biasanya terlihat dalam perumusan mengenai pertanggung jawaban pidana,khususnya yang berhubungan deng an masalah kesengajaan dan kealpaan.

Namun orang yang melakukan tindak pidana belum tentu dijatuhi pidana sebagaimana yang diancamkan, hal ini tergantung pada "apakah dalam melakukan perbuatan ini orang tersebut mempunyai kesalahan", yang merujuk kepada asas dalam pertanggungjawaban dalam hukum pidana : "tidak dipidana jika tidak ada kesalahan ( geen straf zonder schuld; actus non facit reum nisi mens sir rea)". Asas ini memang tidak diatur dalam hukum tertulis tapi dalam hukum tidak tertulis yang juga berlaku di Indonesia. 
Namun lain halnya dengan hukum pidana fiskal, yang tidak memakai kesalahan. Jadi jika orang telah melanggar ketentuan, dia diberi pidana denda atau dirampas. Pertanggung jawaban tanpa adanya kesalahan dari pihak yang melanggar dinamakan (leer van het materiele feit).

\section{B. PEMBAHASAN}

Keberadaan manusia sebagai mahluk sosial tentunya membawa konsekuensi perlunya diciptakan suatu hubungan yang harmonis antara manusia yang satu dengan yang lainnya. Kondisi ini dapat diwujudkan melalui kehidupan saling menghormati dan menghargai bahwa diantara mereka terkandung adanya hak dan kewajiban. Hal seperti ini telah sesuai dengan apa yang telah diamanatkan olen pancasila sebagai dasar Negara dan penjelasan Undang-undang Dasar 1945 (UUD).

Istilah yang dikenal secara universal adalah victimology yang merupakan perkembangan dari kriminologi yang tidak dapat dipisahkan sebagai bagian integral dari kriminologi. Korban kejahatan diartikan sebagai seseorang yang telah menderita kerugian sebagai akibat suatu kejahatan dan atau rasa keadilannya secara langsung telah terganggu sebagai akibat pengalamannya sebagai target (sasaran) kejahatan. Secara teoritis dan praktik pada Sistem Peradilan Pidana Indonesia kepentingan korban kejahatan diwakili oleh Jaksa Penuntut Umum sebagai bagian perlindungan masyarakat sesuai teori kontrak sosial (social contract argument) dan teori solidaritas sosial (social solidary argument).

Korban kejahatan mempunyai peranan yang fungsional dalam terjadinya kejahatan. Dan dalam pengertian yang luas korban kejahatan bukan saja keluarga dan teman korban tetapi juga badan hukum dan badan usaha, kelompok, organisasi maupun Negara karena badan-badan maupun kelompok-kelompok dapat menjalankan hak dan kewajibannya dengan dilindungi hukum. Akan tetapi kadang kala korban juga sebagai pelaku, contoh dalam kejahatan narkotika.

Guna memberikan rasa aman dan nyaman bagi masyarakat dalam beraktivitas, tentunya kejahatan ini perlu ditanggulangi baik melalui pendekatan yang sifatnya preemptif, preventif maupun refresif, dan semua harus ditangani secara profesional serta oleh suatu lembaga yang berkompeten. Berkaitan dengan korban kejahatan, perlu dibentuk suatu lembaga khusus untuk menanganinya.

Van Boven seorang pelapor khusus PBB mengemukakan hak-hak korban pelanggaran Hak Asasi Manusia secara komprehensif yang tidak hanya terbatas pada hak untuk tahu (right to know) dan hak atas keadilan (right to justice) tetapi juga hak atas reparasi (right to reparation). 
Berdasarkan penyelidikan Van Boven, hak-hak tersebut sudah terangkai didalam berbagai instrumen-instrumen hak asasi manusia yang berlaku, dan sudah ditegaskan pula dalam putusan-putusan (yurisprudensi) komite-komite hak asasi manusia internasional maupun pengadilan regional hak asasi manusia. (Theo Van Boven, 2002:26).

Arti penting yang dimaksud dengan hak reparasi atau lebih sering kita dengar dengan istilah seperti kompensasi, rehabilitasi dan restitusi yang bisa diterjemahkan sebagai proses pemulihan yaitu suatu hak yang menunjuk kepada semua tipe pemulihan baik material maupun non material bagi korban pelanggaran hak asasi manusia; pemulihan ini sering disebut dengan istilah kompensasi, rehabilitasi dan restitusi.

Pengaturan hukum pidana terhadap korban kejahatan dikenal dengan 2 model yaitu model hak-hak prosedural dan model hak-hak pelayanan. Yang dimaksud dengan model hak-hak prosedural yaitu si korban diberikan hak berperan aktif dalam proses persidangan di pengadilan dan mendudukkan sikorban sebagai seorang subjek yang harus diberi hak-hak yuridis yang luas untuk mengejar kepentingannya. Sedangkan model hak-hak pelayanan, penekanan diletakkan pada perlunya diciptakan standar-standar baku bagi pembinaan korban kejahatan.
Pada Deklarasi Milan Tahun 1985 menuangkan bentuk perlindungan yang diberikan mengalami perluasan yang tidak hanya ditujukan pada korban kejahatan (victims of crime), tetapi juga perlindungan terhadap korban akibat penyalahgunaan kekuasaan (abuse of power). Hal ini menunjukkan bahwa perlindungan terhadap korban memperoleh perhatian yang serius tidak hanya dari masing-masing negara, tetapi juga dunia. "Deklarasi PBB memberi perlindungan terhadap korban dengan memberikan restitusi, sehingga korban mendapatkan ganti kerugian atas apa yang telah dideritanya. (Holzgrefe, J.L. dan Robert O. Keohane, 2003:49).

Korban dalam lingkup viktimologi memiliki arti yang luas, karena tidak hanya terbatas pada individu yang secara nyata menderita kerugian tetapi juga kelompok, korporasi, swasta maupun pemerintah, sedangkan yang dimaksud dengan akibat penimbulan korban adalah sikap atau tindakan terhadap korban dan/atau pihak pelaku serta mereka yang secara langsung atau tidak terlibat dalam terjadinya suatu kejahatan.

Kejahatan merupakan suatu cap yang diberikan orang untuk menilai perbuatanperbuatan tertentu, sebagai perbuatan jahat. Dengan demikian maka si pelaku disebut sebagai penjahat. Pengertian tersebut bersumber dari alam nilai, maka ia memiliki pengertian yang sangat relatif, 
yaitu tergantung pada manusia yang memberikan penilaian itu. Menurut aliran kriminologi baru lahir dari pemikiran yang bertolak pada anggapan bahwa perilaku menyimpang yang dianggap sebagai kejahatan.

Setiap terjadi kejahatan, mulai dari kejahatan ringan sampai dengan kejahatan berat, pastilah korban akan mengalami penderitaan, baik yang bersifat materiil maupun imateriil. Penderitaan yang dialami oleh korban dan keluarganya tentu tidak akan berakhir dengan ditangkap dan diadilinya pelaku kejahatan, terlebih apabila penderitaan itu berakibat korban menderita cacat seumur hidup atau meninggal dunia.

Secara teoritis, bentuk perlindungan terhadap korban kejahatan dapat diberikan dalam berbagai cara, bergantung pada penderitaan/kerugian yang diderita oleh korban.

Pelanggaran hukum yang kerap terjadi menimbulkan keresahan masyarakat, dibutuhkan penanganan yang serius terhadap pelaku tindak kejahatan terutamanya tindak pidana perampasan harta benda, sehingga masyarakat merasa terlindungi dan bisa beraktifitas dengan tenang. Pemerintah dan masyarakat dalam hal ini dibutuhkan kerjasama sehingga mampu menyelesaikan permasalahan yang kerap terjadi yang mengakibatkan kerugian bagi korban kejahatan.
Kejahatan yang disebut perilaku menyimpang selalu ada dan melekat pada tiap bentuk masyarakat, tidak ada masyarakat yang sepi dari kejahatan, oleh karena itu upaya penanggulangan kejahatan sesungguhnya merupakan upaya yang terus menerus dan berkesinambungan.

Semakin majunya peradaban manusia, sebagai implikasi dari perkembangan ilmu pengetahuan dan teknologi, muncul berbagai jenis kejahatan berdimensi baru, yang termasuk di dalamnya cyber crime. Sejalan dengan itu diperlukannya upaya penanggulangan untuk menjamin ketertiban dalam masyarakat. dalam perspektif hukum, upaya ini direalisasikan dengan hukum pidana. hukum pidana diharapkan mampu memenuhi cita ketertiban masyarakat.

Asas hukum mempunyai dua fungsi, fungsi dalam hukum dan fungsi dalam ilmu hukum. Asas dalam hukum mendasarkan eksistensinya pada rumusan oleh pembentuk undang-undang dan hakim serta mempunyai pengaruh normatif yang mengikat para pihak, oleh karena itu hukum pidana dalam fungsi pengendalian masyarakat, penyelenggaraan ketertiban dan penganggulangan kejahatan harus berorientasi kepada asasasas tersebut. Tindak pidana pencurian diatur dalam Pasal 362 KUHP, selain itu diatur pula dalam Pasal 363 KUHP (pencurian dengan pemberatan), Pasal 364 KUHP (pencurian 
ringan), Pasal 365 KUHP (pencurian yang disertai dengan kekerasan/ancaman kekerasan, Pasal 367 KUHP (pencurian di lingkungan keluarga).

Pertanggungjawaban pidana adalah pertanggungjawaban orang terhadap tindak pidana yang dilakukannya.. Pertanggungjawaban pidana pada hakekatnya merupakan suatu mekanisme yang dibangun oleh hukum pidana untuk bereaksi terhadap pelanggaran atas 'kesepakatan menolak' suatu perbuatan tertentu. (Chairul Huda, 2006:68).

Konsep sentral didalam pertanggungjawaban pidana adalah adanya asas 'tiada pidana tanpa kesalahan' (geen straf zonder schuld). Didalam KUHP tidak dijelaskan mengenai kualifikasi pertanggungjawaban yang dimaksud dalam hukum pidana. Di dalam pasal 44 KUHP hanya menyebutkan bentuk negatif dari pertanggungjawaban pidana. Dua keadaan dimana seseorang tidak dimungkinkan untuk bertanggungjawab terhadap tindak pidana yang ia lakukan. Keadaan yang berkaitan dengan kejiwaan seseorang, dimana dalam hal ini melibatkan disiplin ilmu lain dalam mengkaji hal ini. Kejiwaan yang dimaksud disini tidak saja orang gila yang terganggu akal dan nalarnya tetapi berbagai penyakit kejiwaan lainya salah satunya (Curi Patologis) Kleptomania. Orang dengan kleptomania selalu mengambil barang milik orang lain demi mendapatkan rasa puas setelah melakukan tindakan mencuri tersebut. Mencuri didalam KUHP merupakan suatu delik yang diatur didalam pasal 362 KUHP.

Hukum pidana mengkualifikasikan pertanggungjawaban pidana kedalam: mampu bertanggungjawab, tidak mampu bertanggungjawab untuk sebagian, dan kurang mampu bertanggungjawab. Gangguan kejiwaan curi patologis (kleptomania) dalam hukum pidana dimasukkan kedalam klasifikasi tidak mampu bertanggungjawab untuk sebagian. Artinya, untuk tindak pidana yang berkaitan dengan gangguan kejiwaannya orang dengan kleptomania tidak dapat bertanggungjawab.

Akan tetapi untuk perbuatan lain diluar penyakit kejiwaan (mencuri) yang ia derita, ia mampu bertanggungjawab penuh. Seorang dengan kleptomania memiliki ciri penting, yaitu kegagalan rekuen untuk menahan impuls untuk mencuri bendabenda yang tidak diperlukan, untuk pemakaian pribadi, atau yang memiliki arti ekonomi.(Harold I. Kaplan, Benjamin J. Sadock, dan Jack A. Grebb, 2010:240).

Untuk membedakan antara pencurian yang dilakukan orang dengan kleptomania, dan pencurian biasanya, haruslah dilihat hal berikut ini: seorang dengan kleptomania mencuri harus selalu mengikuti kegagalan untuk menahan impuls; harus merupakan tindakan yang tersendiri; dan benda-benda yang dicuri tidak boleh memiliki arti kegunaan 
ataupun tujuan keuangan. Pada pencurian biasanya, tindakan pencurian biasanya direncanakan; dan benda-benda yang dicuri untuk digunakan atau memiliki nilai finansial.

Jadi pelaku tindak pidana terhadap perampasan barang dapat dipidana dengan penderitaan atau nestapa yang sengaja dibebankan kepada orang yang melakukan perbuatan yang memenuhi unsur syaratsyarat tertentu, sedangkan pidana adalah reaksi atas delik, dan ini berwujud suatu nestapa yang dengan sengaja dilimpahkan Negara kepada pembuat delik.

Sesuai dengan pasal 10 KUHP pelaku tindak pidana bisa dikenai Jenisjenis Pidana sebagaimana telah diatur dalam Pasal 10 Kitab Undang-Undang Hukum Pidana (KUHP):

A. Pidana Pokok

1. pidana mati;

2. pidana penjara;

3. pidana kurungan;

4. pidana denda;

5. pidana tutupan.

B. Pidana Tambahan

1. pencabutan hak-hak tertentu;

2. perampasan barang-barang tertentu;

3. pengumuman putusan hakim.

Sesuai pada Pasal 10 KUHP tersebut diatas maka sanksi terhadap pelaku tindak pidana perampasan barang milik orang lain adalah sebagai berikut : a. Jika pencurian itu adalah pencurian biasa pada Pasal 362 KUHP, pelaku dikenai sanksi penjara paling lama 5 tahun atau denda paling banyak Rp 900,-

b. Jika pencurian itu diperberat maka pelaku dikenai sanksi pidana paling lama tujuh tahun jika dilakukan pada malam hari dan apabila pencurian dilakukan oleh dua orang atau lebih dengan bersekutu serta dilakukan dengan merusak, memotong atau memanjat, memakai anak kunci palsu, perintah palsu, atau pakaian jabatan palsu dipidana penjara paling lama sembilan tahun sesuai Pasal 363 KUHP,

c. Pencurian yang didahului, disertai atau diikuti dengan kekerasan atau ancaman kekerasan dikenai sanksi pidana penjara paling lama sembilan tahun dan apabila pencurian tersebut didahului, disertai atau diikuti dengan kekerasan atau ancaman kekerasan pada malam hari dengan bersekutu serta dilakukan dengan merusak, memotong atau memanjat, memakai anak kunci palsu, perintah palsu, atau pakaian jabatan palsu dipidana penjara paling lama dua belas tahun sesuai Pasal 365 KUHP.

Selain itu pelaku tindak pidana perampasan juga harus memberikan ganti rugi terhadap korban jika tindak pidana tersebut dilakukan dengan kekerasan dan 
menimbulkan luka atau cacat terhadap korban tindak kejahat yang dilakukan, jika sanksi pidana hanya berupa kurungan tidak ada bentuk pertanggung jawaban dari pelaku terhadap korban sehingga perlindungan terhadap korban kurang diperhatikan. Maka dari itu pemerintah harus tegas terhadap pelaku kejahatan sehingga tidak terulang kembali kejahatan yang menimbulkan keresahan bagi masyarakat.

Tujuan pemidanaan adalah mencegah dilakukannya kejahatan pada masa yang akan datang, tujuan diadakannya pemidanaan diperlukan untuk mengetahui sifat dasar hukum dari pidana. bahwa "malim pasisionis propter malum actionis" yaitu penderitaan jahat menimpa dikarenakan oleh perbuatan jahat. Berdasarkan pendapat tersebut, tampak adanya pertentangan mengenai tujuan pemidanaan, yakni antara mereka yang berpandangan pidana sebagai sarana pembalasan atau teori absolute dan mereka yang menyatakan bahwa pidana mempunyai tujuan yang positif atau teori tujuan, serta pandangan yang menggabungkan dua tujuan pemidanaan tersebut, baik saksi pidana dan pertanggung jawaban pidana oleh pelaku terhadap korban.

Tujuan pemidanaan mempunyai tujuan yang plural, yang merupakan gabungan dari pandangan utilitarian yang menyatakan bahwa tujuan pemidanaan harus menimbulkan konsekuensi bermanfaat yang dapat dibuktikan, keadilan tidak boleh melalui pembebanan penderitaan yang patut diterima untuk tujuan penderitaan itu sendiri, misalnya bahwa penderitaan pidana tersebut tidak boleh melebihi ganjaran yang selayaknya diberikan pelaku tindak pidana.

\section{KESIMPULAN}

Korban kejahatan mempunyai peranan yang fungsional dalam terjadinya kejahatan dan dalam pengertian yang luas korban kejahatan bukan saja keluarga dan teman korban tetapi juga badan hukum dan badan usaha, kelompok. Bentuk perlindungan terhadap korban kejahatan yang lazim diberikan, antara lain Pemberian Restitusi dan Kompensasi, Pemberian Konseling, Pelayanan/Bantuan Medis, Bantuan Hukum, Pemberian informasi adalah Pemberian informasi kepada korban atau keluarganya berkaitan dengan proses penyelidikan dan pemeriksaan tindak pidana yang dialami oleh korban, dengan demikian korban tindak pidana kejahatan dapat merasa terlindungi dengan baik dan mendapat perhatian dari pemerintah.

Sanksi terhadap pelaku tindak pidana perampasan barang milik orang lain Jika pencurian itu adalah pencurian biasa pada Pasal 362 KUHP, pelaku dikenai sanksi penjara paling lama 5 tahun atau denda paling banyak Rp 900. Tindak pidana pencurian itu diperberat maka pelaku 
dikenai sanksi pidana paling lama tujuh tahun jika dilakukan pada malam hari dan apabila pencurian dilakukan oleh dua orang atau lebih dengan bersekutu serta dilakukan dengan merusak, memotong atau memanjat, memakai anak kunci palsu, perintah palsu, atau pakaian jabatan palsu dipidana penjara paling lama sembilan tahun sesuai Pasal 363 KUHP. Pencurian yang didahului, disertai atau diikuti dengan kekerasan atau ancaman kekerasan dikenai sanksi pidana penjara paling lama sembilan tahun dan apabila pencurian tersebut didahului, disertai atau diikuti dengan kekerasan atau ancaman kekerasan pada malam hari dengan bersekutu serta dilakukan dengan merusak, memotong atau memanjat, memakai anak kunci palsu, perintah palsu, atau pakaian jabatan palsu dipidana penjara paling lama dua belas tahun sesuai Pasal 365 KUHP.

Selain itu pelaku tindak pidana perampasan juga harus memberikan ganti rugi terhadap korban jika tindak pidana tersebut dilakukan dengan kekerasan dan menimbulkan luka atau cacat terhadap korban tindak kejahat yang dilakukan, jika sanksi pidana hanya berupa kurungan tidak ada bentuk pertanggung jawaban dari pelaku terhadap korban sehingga perlindungan terhadap korban kurang diperhatikan.

\section{DAFTAR BACAAN}

Chairul Huda, Dari Tiada Pidana Tanpa Kesalahan Menuju Kepada Tiada Pertanggungjawaban Pidana Tanpa Kesalahan, Cetakan Kedua, Kencana, Jakarta, 2006.

Departemen Pendidikan dan Kebudayaan. Kamus Bahasa Indonesia, lakarta, 2001.

Harold I. Kaplan, Benjamin J. Sadock, dan Jack A. Grebb, Sinopsis Psikiatri Ilmu Pengetahuan Psikiatri Klinis, Jilid II, Bina Rupa Aksara, Tanggerang, 2010.

Holzgrefe, J.L. dan Robert O. Keohane. Humanitarian Intervention: Ethical, Legal, and Political Dilemmas. Cambridge: Cambridge University Press. 2003.

Kitab Undang-Undang Hukum Pidana (KUHP) Dilengkapi Yurisprodensi. 2006. Mahkamah Agung dan Hoge Raad, PT. Raja Grafindo Persada, Jakarta.

Kitab Undang-Undang Hukum Acara Pidana (KUHAP), LN No.76 Tahun 1981, TLN No. 3209 


\title{
ANALISIS PASAL 1242 KITAB UNDANG-UNDANG HUKUM PERDATA UNTUK \\ TIDAK BERBUAT SESUATU SEBAGAI HAK DAN KEWAJIBAN DALAM \\ PERJANJIAN PINJAM MEMINJAM
}

\author{
SUTRISNI \\ Fakultas Hukum Universitas Wiraraja Sumenep \\ sutrisnioke@yahoo.com \\ YAYUK SUGIARTI \\ Dosen Fakultas Hukum Universitas Wiraraja Sumenep \\ Yayuksugiarti66@yahoo.co.id
}

\begin{abstract}
ABSTRAK
Suatu perjanjian dapat timbul karena adanya kesepakatan antara para pihak yang sepakat untuk melaksanakan perjanjian tersebut sebagaimana mestinya. Di dalam suatu perjanjian para pihak memiliki hak dan kewajiban yang harus dihormati dan dilaksanakan dengan baik. Apabila salah satu pihak tidak melaksanakan perjanjian yang telah disepakat, maka pihak tersebut melakukan wanprestasi. Untuk mengetahui pihak tersebut melakukan wanprestasi yaitu apabila tidak memenuhi prestasi sesuai waktu yang telah disepakati.

Untuk memberikan peringatan terhadap pihak yang melakukan wanprestasi agar dapat segera memenuhi prestasi,yaitu dengan dilakukan peringatan tertulis secara resmi dan peringatan tertulis secara tidak resmi. Peringatan tertulis secara resmi dapat dilakukan melalui pengadilan negeri yang berwenang, sedangkan peringatan tertulis tidak resmi dapat dilakukan melalui surat tercatat,telegram,faksimile atau disampaikan secara langsung terhadap pihak yang bersangkutan.
\end{abstract}

Kata Kunci : Tidak berbuat sesuatu, hak dan kewajiban, perjanjian pinjam meminjam.

\section{A. PENDAHULUAN}

Untuk mewujudkan suatu perjanjian yang telah disepakati bersama, para pihak yang terikat dalam perjanjian dapat melaksanakan isi perjanjian sebagaimana mestinya. Dilaksanakannya prestasi dalam perjanjian, maka apa yang diharapkan sebagai maksud dan tujuan diadakannya perjanjian akan tercipta dengan baik tanpa ada pihak yang dirugikan yang dapat menuntut atas kerugian yang dideritanya. Perjanjian kerja memegang peranan penting dan merupakan sarana untuk mewujudkan hubungan kerja yang baik dalam praktek sehari-hari.
Adanya perjanjian kerja, pengusaha harus mampu memberikan pengarahan/penempatan kerja sehubungan dengan adanya kewajiban mengusahakan pekerjaan atau menyediakan pekerjaan, yang tidak lain untuk mengurangi jumlah pengangguran Indonesia, akibat pertumbuhan penduduk yang semakin tinggi dan penyebaran penduduk yang kurang seimbang sehingga menjadi faktor yang amat mempengaruhi tentang masalah ketenagakerjaan di Indonesia. Namun, saat ini masih banyak pekerja yang tidak mengerti akan hak dan kewajibannya sehingga banyak pekerja yang merasa 